\title{
THE USE OF PROJECT BASED LEARNING AND PEER ASSESSMENT TO IMPROVE STUDENTS' SPEAKING SKILL FOR YOUNG LEARNERS
}

\author{
* Dwi Endah Widyastuti ${ }^{1}$ \\ ${ }^{1}$ STIE Tribuana, Bekasi, Indonesia \\ *Coresponding author. \\ E-mail addresses: dwiendahwidyastuti@gmail.com
}

\begin{abstract}
ARTICLE INFO
Article history:

Received:

3 March 2021

Accepted:

15 April 2021

Available online:

4 Mei 2021

ABSTRACT

Project Based Learning is a learning method to encourage knowledge building through collaborative learning and usually integrated with real world concerns. Peer Assessment is an effective way to may help learners reflect on their own project work and improve their speaking skill. In addition the peer-assessment is useful as guidance for the students' projects. This research aimed to find out the impact of project based learning and peer assessment learning to improve students'speaking skill and the benefits of PBL and Peer Assessment. This research was conducted at the seventh grade of SMPN 2 Babelan-Bekasi, from 12 September until 10 October 2017. It involved only one class is the students of VII.1 in SMPN 2 Babelan-Bekasi. This class consists of 30 students with 17 females and 13 males. This research was a classroom action research that consist of three cycles. Each cycles has four steps, they are; planning, acting, observing and reflecting. The researcher answered the research questions by using four instruments such as observation, interview, test and questionnaire. The results of this research revealed that first, PBL and Peer Assessment could improve students' speaking skill. Second, talked a lot, they were participating each other, it motivated them to speak more, to be an enthusiasm and to be independent learner. Besides, the number of errors in speaking components was significantly decreased after they were encouraged to assess by peer. Based on the theories and previous studies, it can be concluded that there were positive effects; the peer assessment which apply in Project Based Learning (PBL) has positive in teaching speaking. Peer assessment helped the students in speaking English and peer corrective about their performance, so it built their motivation in developing of speaking skill.
\end{abstract}

Keyword: Project Based Learning, Peer Assessment, Speaking Skill.

\section{INTRODUCTION}

In language teaching, project-based learning (PBL) has become more popular. The concept of Project-based learning as a learning method or technique which focuses on the learner; the teacher roles as a facilitator and motivator. Based on another research PBL emphasizes learning activities that are learner centered and usually integrated with real world concerns. (Moss and Van Duzer 1998) define Project Based Learning as an instructional approach that contextualizes learning by presenting learners with problems to solve. As dealt with in (Stoller 2006) provides opportunities for the natural integration of all four skills, reading, writing, listening 
and speaking. The final outcome of the project here, for example bulletin board display, written report, debate competition, brochure, advertisement, poem, letter, handbook, oral presentation, video, multimedia presentation, and theatrical performance.

The Benefit of PBL according to (I. Lee 2002), is students have enhanced motivation, engagement and enjoyment because project work progresses according to the specific context and students' interests. And he said that projects being authentic tasks are more meaningful to students, increase interest, motivation to participate, and can promote learning. Why? Because a project may be connected to real professions through the use of authentic methods, practices, and audiences. In addition, PBL can develop skills for the students. (Coleman 1992) discusses a benefit relating to students increased social, cooperative skills, and group cohesiveness.

\section{LITERATURE REVIEW}

Based on the previous study, adopting PBL projects in the classroom also helps reinforce social relationships among team members and also enhances collaboration among learners, between learners and the teacher. PBL also provides learners with opportunities to learn collaborative skills, such as relying on the work of peers and providing thoughtful feedback to peers. Involving students in pairs and groups; this practice stimulates cooperation and it encourages individual students to talk more.

The researcher focused on speaking which is apply in project based learning. Based on the observation the students had difficulties in speaking and pronounce the correct words and they are afraid to speak in front of their teacher or the class. The student has different level of capability and understanding. To confront the different learners' characteristics also require special competence from the teacher, for example in creating teaching technique or method. In teaching learning process, teaching is the most important aspect must be noticed, but in addition assessment from the learning process also needed.

(Taras 2005:467) defines assessment as judgements of students'work, and evaluation. To refer to judgement regarding courses or course delivery, or the process of making of such judgements. (Nurgiyantoro 2011:7) argues that assessment is a systematic process in collecting, analysing, and interpreting the information to determine how far the learners can reach the goal of education. It can be concluded that assessment is judgement based on several criteria to know the learners understanding. So many forms of alternative assessment which have been applied widely in the field of language assessment, such as students' journals, portfolios, selfassessment, peer-assessment, conferences, and interviews (Brown, 2003). Peer-assessment is "an educational arrangement where students judge a peers' performance quantitatively and/or qualitatively and which stimulates students to reflect, discuss and collaborate" (Strijbos \& Sluijsmans 2010, p. 265). This research tries to describe the implementation of peer assessment and project based learning on students' speaking skill and also tries to find out the impact of peer assessment which is apply in project based learning.

A number of previous studies have been conducted in this area. Arista Nur Prihatini (2015) was conducted a study to explore the effect of peer assessment on speaking in project learning. She found that peer assessment in project learning had postive impact on the motivation of the students in developing their speaking.

In another study, (McDonald, B. 2008). Assessment for learning - in Project-Based Learning. It means assessment by self, peers, and supervisors are all needed in PBL. McDonald provided several assessment models and rubric forms. McDonald found that even though their students tended to rate themselves higher than the teacher's evaluations, the peer-assessment forms were useful as guidance for the students' work during the projects and for their presentations. It means that a good assessment tool can become an effective learning tool in a school. The article can be concluded that instructor need to consider their own teaching circumstances, as well as the project objectives in order to suit the assessment models to their own classes.

(Hunaiti, Z., Grimaldi, S., Goven, D.,Mootanah, R., \& Martin, L. 2010). Their study about principles of assessment for Project and Research Based Learning. This article outlines principles of assessment for PBL and the author's case study. The underlying principle in this article is that learning is a constructivist system. Therefore, both formative assessments, such as self and peer evaluation and summative assessments on the work in the project, such as written reports like headline news and poster presentations, are important in assessment in PBL. According to them, one of the most important points in assessment is that teachers need to provide an atmosphere where students are willing to give and get feedback, improve their learning, and make their performance better. Based on the result, students' learning styles, strengths, and weaknesses are different; therefore, teachers need to be flexible in designing assessments and offer different types of assessments throughout a project in order to assess each individual's full potential. The result showed that by having choices for setting up their own goals and criteria and reflecting on their own learning, students will be motivated to 
learn spontaneously. Hunaiti also reminded readers that like with all assessment forms, assessment in PBL should be "valid, reliable and transparent" (p. 194). It means, specifically, to make assessment transparent, the assessment tool needs to define learning outcomes and assessment criteria well.

(Martin Valcke and Irene Roozen 2009) conducted a study. This study focused on the agreement between professional assessment or teacher assessment and peer assessment of oral presentation skills and explores student perceptions about peer assessment. All the presentations were recorded. Oral presentations about a prescribed topic. Topics were of similar difficulty level: my house, my school, my university. The evaluation of the oral presentations by the teachers and peer assessors was based on video recordings. The rubric was introduced as part of the instruction package. The rubric sum score reported by teachers is significantly lower as compared to the peer assessments.

The result of this study showed a comparison between the teacher and peer assessment rubric scores points at a positive relationship, but also at critical differences. The peers and teachers still interpret the criteria and indicators of the rubric in a different way. With regard to the comparison of peer-assessment scores and teacher scores, it can be concluded there is a level of agreement and disagreement when assessing the oral presentations. And also the finding that the peer-assessment scores are, mostly, higher than the marks given by teachers is consistent with the results reported in the literature. As stated above, these scoring differences can be explained by the broader experience of teachers when judging the quality of oral presentations. They can retrieve from their memory a larger set of models that exemplify how oral presentations.

Based on the previous studies described that in the context of project-based learning, peer assessment has a vital role in speaking by involving students in judging the work of their colleagues. Peer assessment may help learners reflect on their own project work and improve their speaking skill. In addition the peer-assessment is useful as guidance for the students' projects.

The differentiate the researcher's study from previous studies are the participants of study, the setting and place of study and the design of study. The researcher focus on young learners in implementing PBL and Peer Assessment. Those young learners are chosen because they need to focus on speaking since they have problems in mastering the elements of language. The researcher conducted this study in two months, started from $1^{\text {th }}$ of September for the seventh grade students of SMPN 2 Babelan in the 2017/2018 Academic Year. In this study, the researcher used the qualitative research with classroom action research. This research conducted in three cycles. It was conduct based on the English teacher and the researcher's target to minimalize the students who got the score under score criteria minimum.

\section{METHODS}

Based on the review of related literature, the research questions are addressed:

1. How is the improvement of students' speaking skill through project based learning and peer assessment on the young learners?

2. What are the problems faced by the students on the seventh grade as the young learner?

3. What are the young learners' responses to the application of the PBL and Peer Assessment?

In this study, the researcher used the qualitative research with classroom action research developed by Kemmis $\&$ Mc. Taggart (2005) since it focuses on a particular problem and a particular group of students in a certain classroom. This research consists of three cycles. Kemmis \& Mc. Taggart say that "each cycles have four steps, they are: planning, acting, observing and reflection." Classroom action research is a guide for teacher to improve the performance or enhance the quality of learning in a sustainable manner that essentially saw the implementation of professional educators who embrace the mission of the teacher.

The subject of this research consists of thirty students at VII-1 class in 2 Babelan Junior High School in 20172018 academic years. The student has different level of capability and understanding. Some of students have difficulties in speaking and pronounce. To confront the different learners' characteristics also require special competence from the teacher.

The researcher got the data from all information of students' activities like field note of the observation. The sources of the data can be obtained from; event, informant, and document. The researcher used instruments of collecting data namely; observation, interview, documentation. The researcher used three steps of technique for analyzing data namely; reducing data, displaying data, and data verification.

\section{RESULT AND DISCUSSION}


Based on the students' score that they got after implementing PBL and Peer Assessment, the result of the research could be explained as follows: The cycle I on the result of the average students' score is 68.93. It means that the students' score increase $56.7 \%$ (there were 17 students could achieve KKM score, $17 / 30 \times 100 \%=$ $56.7 \%$ ). Based on the result of observation in cycle 1 showed that some students could not pronounce some words well. Based on the result of interview, the students could not pronounce words because of the words were so difficult for them to pronounce. And also the result of peer assessment showed that some students had different assessment with the researcher. The result of peer assessment was higher than the result of the researcher. To solve this problem the researcher modified the strategy in teaching in cycle two. In cycle two, the researcher used mind mapping in describing an animal. The researcher showed some words and how to pronounce on video. Then the researcher asked the student to create mind mapping based on the picture of animal and also presented their oral project.

In the cycle II, there was improvement on students' achievement. The average score is 73.33 . It means that the students' score increase $76.7 \%$ or there were 23 students could achieve standard score, $23 / 30 \times 100 \%=$ $76.7 \%$. Based on the observation in cycle 2 , some students could pronounce well, but their fluency was not good. Some students spoke with some long pauses "em..". because of the words too long. To solve this problem, the researcher modified the teaching strategy to solve students' problem in fluency. The researcher used pictures in cycle 3 to helped them. The researcher asked the students to describe a picture about the activity on the picture.

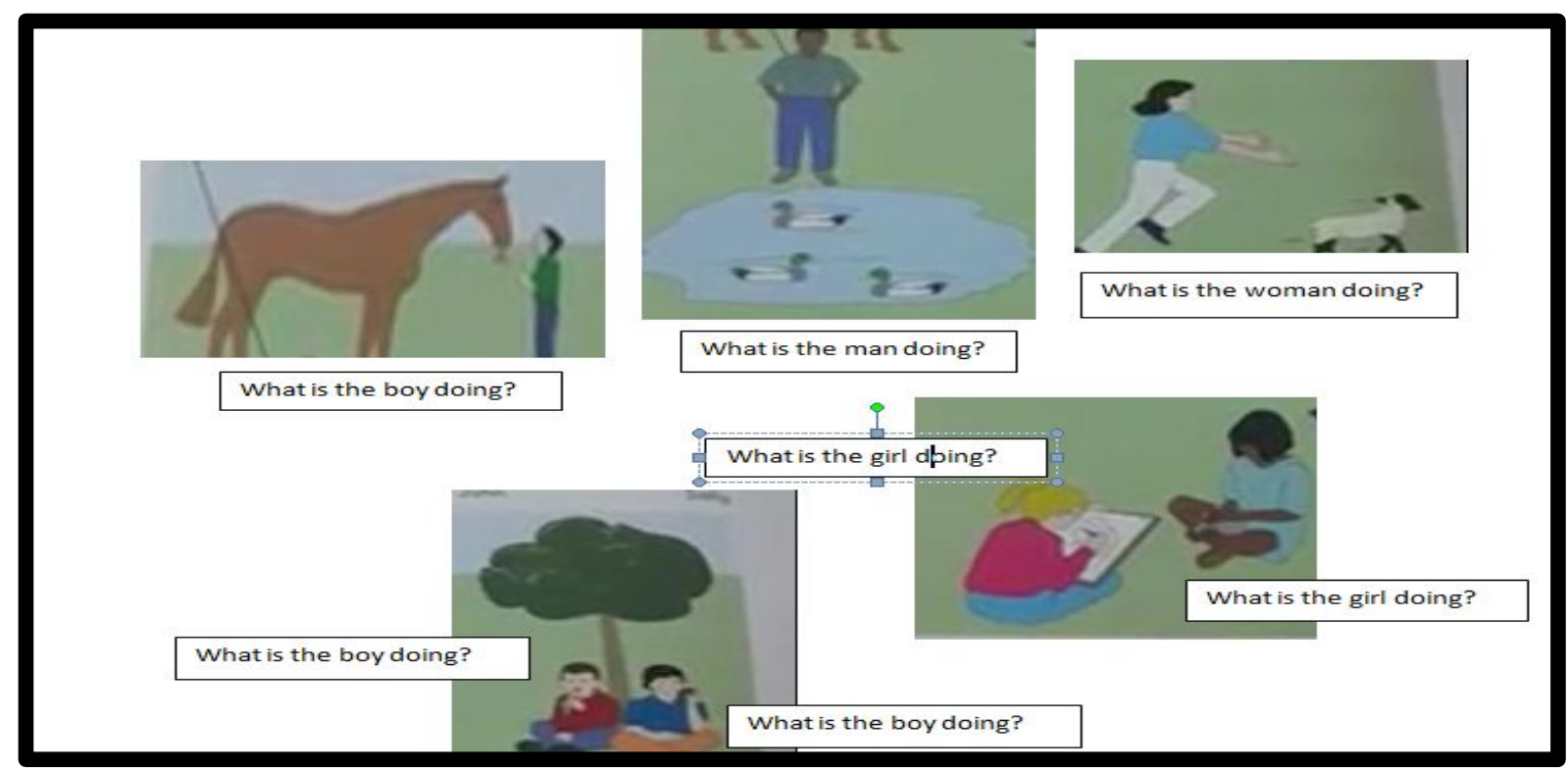

Picture 1. Descriptive Text

In the cycle III. The average of students' score is 80.00 . It means that the students' score increase $93.3 \%$ (there were 28 students could achieve standard score, $28 / 30 \times 100 \%=93.3 \%$. Based on the observation in cycle 3 showed that some students got mistakes in describing because of the students could not comprehend the picture. To solve this problem, the researcher helped them in giving some pieces of text based on the picture to match the text with the picture. 


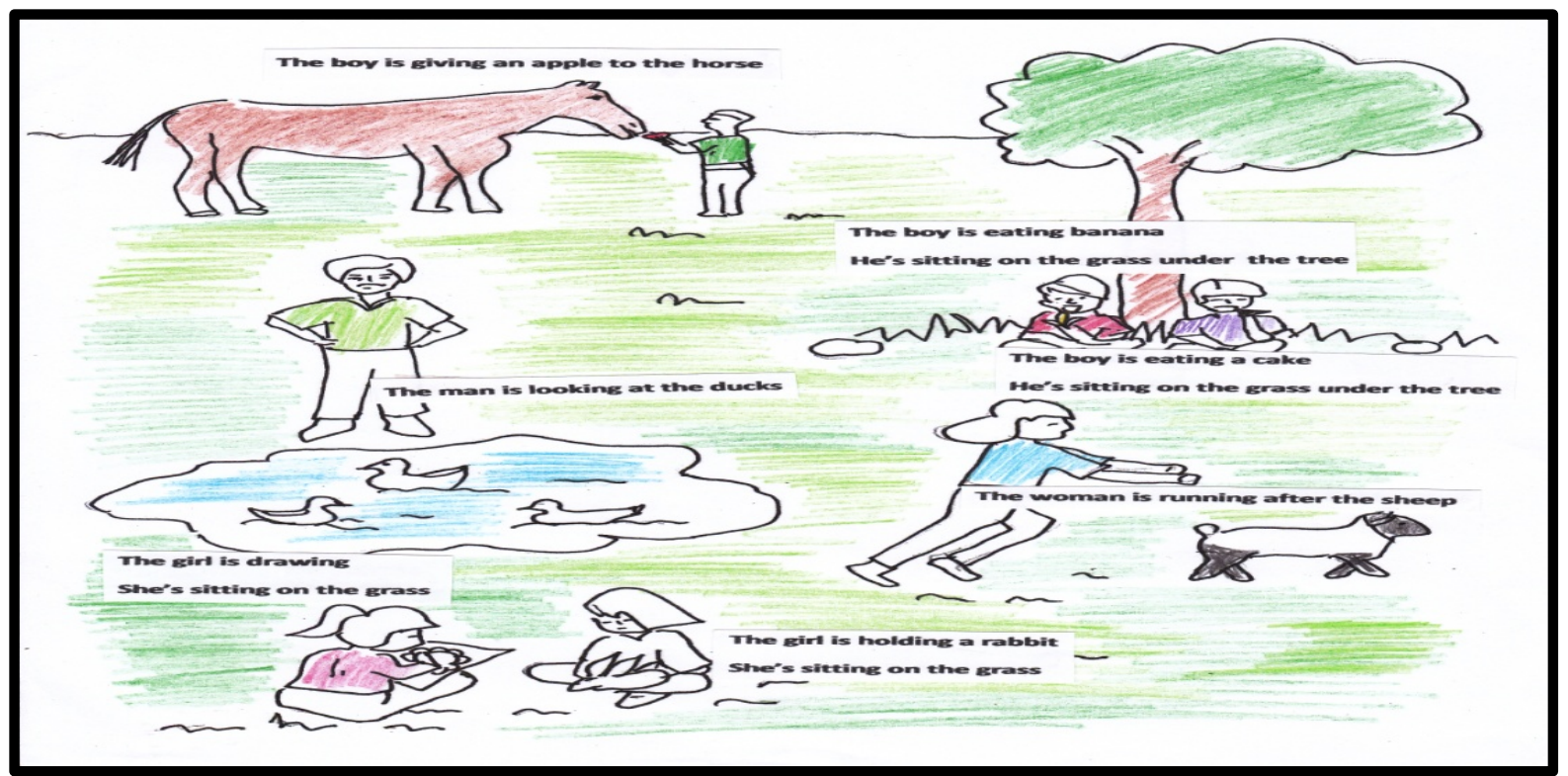

Picture 2. Descriptive Text

But, on the result of peer assessment, some students had similarity with the researcher. Based on the result of interview showed that the video modelling could help them in assessing their partner based on rubric. The researcher and the collaborator felt satisfied because the students had significant improvement from the score they got from pretest, posttest 1 and posttest 2 and also from component in speaking. They could pronounce, comprehend well. The result of the speaking test could achieve the target score; $85 \%$, so that the researcher did not continue this research to the next cycle.

The result of study showed the similarities with Martin Valcke and Irene Roozen (2009). Martin and Irene conducted a study. This study focused on the agreement between professional assessment or teacher assessment and peer assessment of oral presentation skills and explores student perceptions about peer assessment. All the presentations were recorded. The students assessed their peer used rubric. The result of this study showed a comparison between the teacher and peer assessment rubric in giving scores. With the differential of peerassessment scores and teacher scores, it can be concluded there is a level of agreement and disagreement when assessing the oral presentations. The finding that the peer-assessment scores were mostly higher than the marks given by teachers. This can be explained by differences in the width and depth of their experience basic

The researcher's study also got differences when assessing the oral presentation as the speaking project. It decribed that the peer assessment scores mostly higher than the marks given by the researcher as the teacher. The students' perceptions of peer assessments influenced their willingness to take into account the feedback generated by peer assessment and do something with the feedback.

The achievement could be more enhanced if PBL and also peer assessment can be applied in daily teaching learning process. However, the time alloted for thus research was not especially designed but taken from the time was alloted for the four skills. Meanwhile, this research focused only on part of one skill. Thus the cycle procedure could not be done out of the way from other teaching procedures. To make clear about the result above, it can be seen through the diagram below:

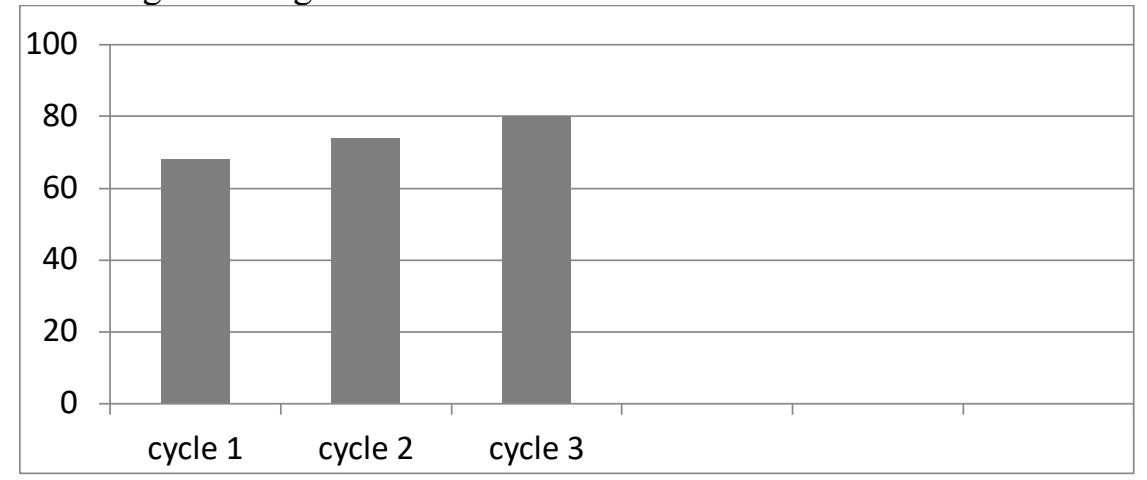

Picture 3. The percentage of students' achievement 
From the data analysis, it was found that students' speaking skill was increasing in each cycle. The result of students' score in every cycle can be seen in appendix. In cycle one, the average score was 68,93 . In cycle two, the average score was 73.3. In cycle three, the highest score was 80.00 . The result of interview showed that the PBL and peer assessment could improve students' speaking skill and their motivation. And this technique was very interesting because oral presentation as the speaking project was assessed and most participants (students) played the role of assessor and assessee. So, they became more aware of their mistakes during oral presentation.

\section{CONCLUSION AND RECOMMENDATION}

Based on the result of studies showed that the use of peer assessment and project based learning could improve students' speaking skill; could help the students' understanding of correct pronunciation by getting correction, the student commenting peers as the definition of speaking, "speaking is oral interaction which are conventional was of presenting information, expression, our idea, and thought", Nunan (1991:40). It is also appropriate with the advantages of peer assessment by Cassidy (2006:509) that it is potential for providing increased student responsibility and evaluative skill.

\section{REFERENCES}

Arista Nur Prihatini. 2015. The Implementation of Peer Assesment on Speaking in Project Learning. School of teacher training and education; Muhammadiyah University of Surakarta

Brown, H. D. 2003. Language Assessment: Principles and Classroom Practices. San Francisco: Pearson Longman

Cassidy, S. 2006. Developing Employability Skills: Peer Assessment in Higher Education, Education \& Training, 48 (7), pp. 508-517.

D. Moss, \& C. Van Duzer. 1998. Project-based learning for adult English language learners. NationalClearinghouse for ESL Literacy Education.

F. Stoller, Project work (1997). A means to promote language content, English Teaching Forum Online, 35(4).

G. H. Beckett \& P. C. Miller. 2006. Project-based second and foreign language education: Past, present, and future. Charlotte, NC: Information Age Publishing, 241-259

Heigham, Juanita \& Croker, Robert A. 2009. Qualitative Research in Applied Linguistic A Practical Introduction. Fourth Edition. Britain: Palgrave Macmillan.

Hunaiti, Z., Grimaldi, S., Goven, D., Mootanah, R., \& Martin, L. 2010. Principles

I, Lee. 2002. Project work made easy in the English classroom, Canadian Modern Language Review, 59, 282290

J. A. Coleman. 1992. Project-based learning, transferable skills, information technology and video, Language Learning Journal, 5, 35-37.

J. W., \& Sluijsmans, D. 2010. Unravelling peer assessment: Methodological, functional, and conceptual developments. Learning and Instruction, 20(4), 265-269.

J. W., \& Sluijsmans, D. 2010. Unravelling peer assessment: Methodological, functional, and conceptual developments. Learning and Instruction, 20(4), 265-269.

Margono, S. 2000. Metodologi Penelitian Pendidikan. Jakarta : PT Rineka Cipta Strijbos,

McDonald, B. 2008. Assessment for learning in project-based learning. International Journal of Learning, 14(10), 15-27.

Nunan, David. 1991. Language Teaching Methodology. London: Prentice Hall

Nurgiyantoro, Burhan. 2011. Penilaian Pembelajaran Bahasa. Yogyakarta: BPFE-Yogyakarta.

of assessment for project and research based learning. International Journal of Educational Management, 24(3), 189-203.

Tarras, Maddalena. 2005. Assessment-Summative and Formative-Some Theoretical Reflections. University of Sunderland. 